\title{
The effect of intellectual capital efficiency on financial performance: A research on participation banks
}

\author{
Neşegül Parlak ${ }^{1}$
}

1 Lec. Dr., Ordu University, Fatsa Vocational School, Ordu, TURKEY, e-mail: nparlak@odu.edu.tr

\begin{abstract}
Today, intellectual capital, which is an important element of economic development, plays a key role in increasing profitability and creating institutional value. Intellectual capital represents the invisible assets of the enterprise such as knowledge, experience and information, which will be used to create wealth in the enterprise. The efficiency of intellectual capital is important in terms of ensuring that businesses have a competitive edge in global markets and sustainable performance.

This study was conducted in order to determine the effect of intellectual capital on the financial performance of participation banks. The intellectual capital performance of 6 participation banks operating in Turkey between 2016-2020 was measured through Value Added Intellectual Coefficient (VAIC) Model, and the contribution of intellectual capital performance and performance components to financial performance was examined using Panel Data Analysis method. According to the findings obtained as a result of the research, it was determined that intellectual capital efficiency has an effect on financial performance.
\end{abstract}

Keywords: Intellectual capital, financial performance, panel data analysis.

Jel codes: $M 19$, M49

\section{INTRODUCTION}

Intellectual capital is based on the management of intangible assets rather than tangible assets as an important asset that distinguishes the business from other businesses in an environment of increasing competition along with globalization. In the globalizing economy, it is seen that the intellectual capital comes to the fore for the businesses to gain competitive advantage. Human capital, structural capital and customer capital, which are the elements of intellectual capital in businesses, have an important power in increasing business performance. Human capital, which is the most important one of these elements, is the source of competitive advantage which reveals the difference of enterprises and provides added value, since it has the potential for the production, accumulation, use and sharing of information.

Banks provide the products and services they offer to their customers through employee knowledge and invisible resources. The efficiency level of these resources contributes significantly to banks in ensuring competitive advantage and adding sustainable value. Therefore, the difference that emerges in the performance of banks is related to intellectual capital.

In this study, the effect of the intellectual capital of participation banks operating in Turkey on their performance was examined. It is thought that this study will contribute to the literature. 


\section{INTELLECTUAL CAPITAL}

Intellectual capital is the total sum of what the employees of the enterprise know, which provides the business with a competitive advantage in current market conditions (Stewart, 1991: 47). It is a concept that classifies all invisible resources in the enterprise as human capital, structural capital and customer capital (Bontis et al., 2000). Intellectual capital means the use of knowledge to create wealth, intellectual property information, information and experience (Odabaşığlu, 2019: 1). Intellectual Capital is not a static property; it is a concept that can be applied in line with the needs of the business and expresses dynamism in economic and social terms (Sümerli Sarıül, 2020: 429). The intellectual assets of the business are the information belonging to the business over which it can claim ownership rights, and which is partially qualified with a material identity or defined with a physical meaning (Töre, 2019: 278).

In terms of accounting, intellectual capital can be expressed as the difference between the book value of the business and the value ready to be paid for this value. Intellectual capital, which creates value in line with the targets of companies and provides the opportunity to have a competitive advantage is a term that indicates intangible assets, and knowledge and skills (Özdemir and Kaya, 2019: 269). Elements of intellectual capital can be evaluated under three headings as human capital, structural capital and customer capital.

Human capital represents business employees with their special talents, knowledge, skills, experience and specialization, and an important resource for the business. In ensuring continuity in success, it is deemed necessary to increase business knowledge, skills and experiences and to care about investments that can contribute to the personal development of employees (Stewart, 1997: 95).

Structural capital is the sum of the accumulation of knowledge and the ability to access and use information, business culture, business system, business secrets of the company, product designs and patents (Çıkrıkçı and Daştan, 2002: 22).

Customer capital provides the opportunity to examine the market share of the enterprise, the new customers it has acquired in the market, the existing customers in the portfolio of the enterprise through the distributed profit share and customer satisfaction studies (Önce, 1999: 19).

It is necessary to determine the criteria that will make the intellectual assets that are invisible in the financial statements visible and to measure these criteria using appropriate methods (Özevren and Yildiz, 2010: 275). There are many methods of measuring the intellectual capital. Value Added Intellectual Coefficient method, one of these methods, was developed by Ante Pulic. This method is an analytical method that enables the measurement of the efficiency of the added value created by management levels, shareholders and other benefactors, the total resources of the enterprise, and the basic components of these resources (Demirkol, 2006: 117).

\section{LITERATURE}

When the national and international literature is examined, there are numerous studies examining the impact of intellectual capital on financial performance. It is also possible to find studies in the financial and banking sectors aimed at determining the impact of intellectual capital on financial performance. In the studies conducted, it was generally concluded that intellectual capital positively affected the financial performance of banks. Some of these studies are given below.

Some of these studies included in the international literature are as follows:

Appuhami (2007) examined the data of 33 banking, insurance and other financial institutions traded in the Thailand Stock Market, and determined that there was a positive relationship between intellectual capital and share earnings.

In a study conducted by El-Bannany (2008) the indicators of intellectual capital performance using the VAIC method over the data from the UK banking sector between 1999 and 2005 were examined, and it was determined that there were statistically significant correlations between profitability and risk and intellectual capital performance.

Saengchan (2008) examined the data from the Thailand banking sector between 2000 and 2007, and found a strong relationship between intellectual capital efficiency and financial performance.

In a study conducted on the Malaysian financial sector by Maheran and Khairu (2009), it was found that the provision of added value through physical and financial capital was greater than intellectual capital.

Fayez et al. (2011) measured the intellectual capital efficiency of Kuwaiti banks between 1996 and 2006 using the VAIC method.

In a study conducted by Al-Shubiri (2011), in which the data of 14 commercial banks selected from Amman Stock Exchange Market between 2002 and 2007 were examined, it was determined that there was a significant relationship between financial performance and structural capital efficiency, and that there was a positive correlation between market value and intellectual capital.

In a study conducted by Mondal and Gosh (2012) over tha data of 64 Indian banks between 1998 and 
2009, intellectual capital was found to be a significant determinant of productivity and profitability.

Gigante (2013) examined the 2004-2007 data of the banks traded in stock markets in European countries and emphasized that there was a relationship between intellectual capital efficiency and financial performance of the banks.

Joshi et al. (2013) analyzed the 2006-2008 data of Australian finance sector, and determined that the value creation efficiency of the finance sector was highly affected by human capital.

In a study conducted by Al-Musali and $\mathrm{Ku}$ Ismail (2014) in Saudi Arabia between 2008 and 2010, they determined that performance components of intellectual capital can influence traditional indicators of bank success.

In the study conducted by Ousama and Fatima (2015), it was found that the human capital efficiency of the Islamic banking sector in Malaysia was higher than the efficiency of structural capital and capital used, and that intellectual capital affected profitability.

The studies conducted in our country can be summarized as follows:

Ercan et al. (2003) determined in their study that the relationship between the intellectual capital efficiency and the performances of the banks operating in Turkey and traded in the stock market was limited and complicated, and that despite the banks' efforts to care about their intellectual capital, the main element affecting their performances was the physical assets they had.

In a study conducted by Şamiloğlu (2006), it was examined whether there was a significant relationship between the VAIC values and market value/equity book values of the banks traded in BIST, and a significant relationship was found between certain intellectual capital elements and market value/equity book value.

In the study conducted by Yalama and Coşkun (2007) where the 1995-2004 data of the banks traded in IMKB were examined, it was determined that intellectual capital was a more significant factor the physical capital, and that it was effective on the investors' behaviors.

In the study conducted by Yalama (2013) in which the 1996-2006 data of the Turkish banking sector were analyzed, it was found that intellectual capital was a strong indicator of increasing the profitability, market value and efficiency of banks, especially in the long term.

In the study carried out by Çalışkan (2015) on the 2013 data of 14 banks traded in Borsa Istanbul in Turkey, it was found that human capital was influential on the efficiency and market value of the banks, and first the capital used and then human capital were effective on profitability.

As a result of the study conducted by Ekim et al., (2019) examining the intellectual capital performance of 21 commercial banks operating in Turkey between 2006 and 2015, they concluded that the future performance of the financial and banking sector depended on the efficiency of intellectual capital.

In the study conducted by Öztopanlar (2019) in which the effect of intellectual capital on the performances of banks were demonstrated through VAICTM method, it was concluded that the difference between the performances of the banks resulted from their ability to manage and benefit from intellectual capital, and particularly from their effective use of human capital.

\section{RESEARCH}

\subsection{The Purpose of the Research}

This study was conducted in order to determine the effect of intellectual capital on the financial performance of participation banks. For this purpose, the effect of intellectual capital elements on the financial performance of banks in 6 participation banks operating in Turkey was demonstrated by using panel data analysis. The research is significant in that it is the first study aimed at measuring the effect of intellectual capital efficiency on financial performance in the context of participation banks operating in Turkey.

\subsection{Research Method}

In this study, regarding the 6 banks operating in the field of participation banking in Turkey, physical capital efficiency (PCE), human capital efficiency (HCE), structural capital efficiency (SCE), operating profit margin (OPM), return on equity (ROE), profit capital ratio (PCR), size (SIZE), financial leverage ratio (FLR) and physical capital intensity (PCI) data of the 2016-2020 period were used. In the study, HSE, PCE and SCE were taken as control variables, SIZE, FLR and PCI as independent variables, and ROE, OPM and PCR as dependent variables. 
Table 1: Descriptive Statistics Of The Variables Used In The Stud

\begin{tabular}{lllllll}
\hline Variable & Avg. & SS & Min & Max & Skewness & Kurtosis \\
\hline PCE & 3.272 & 3.132 & 0.274 & 13.440 & 1.907 & 3.081 \\
HCE & 6.119 & 17.693 & 1.403 & 99.442 & 4.883 & 22.799 \\
SCE & 0.599 & 0.168 & 0.287 & 0.990 & 0.298 & -0.694 \\
ROE & 0.008 & 0.004 & 0.001 & 0.016 & 0.043 & -1.106 \\
PCR & 0.101 & 0.056 & 0.017 & 0.213 & 0.030 & -1.311 \\
OPM & 0.268 & 0.477 & 0.073 & 2.772 & 4.806 & 22.303 \\
SIZE & 7.458 & 0.418 & 6.618 & 8.183 & -0.558 & -0.731 \\
FLR & 0.905 & 0.040 & 0.796 & 0.948 & -1.643 & 1.701 \\
PCI & 0.002 & 0.001 & 0.000 & 0.005 & 0.641 & -0.938 \\
\hline
\end{tabular}

Avg .: Arithmetic mean, SD: Standard deviation, Min: Minimum, Max: Maximum

In table 1, descriptive statistics for nine different variables used in the study are given.

These variables selected in the study were selected in the light of the information obtained from the past reference study (Göker, 2017). Hausman test was also used in the selection of effect type.

In the study, primarily for the panel data of dependent and independent variables, Levin-Lin and Maddala-Wu stationarity tests were applied. Hausman test was used in the selection of fixed or random effect type in panel regression models.

To test the auto-correlation and heteroscedasticity assumptions of the models, Breusch-Godfrey (BG) auto-correlation test and Breusch-Pagan (BP) heteroscedasticity test were applied. In cases when these assumptions are violated, panel regression models were estimated with the Driscoll-Kraay estimator (Driscoll and Kraay, 1998), which is resistant to deviations.
Coefficients (Beta) and significance values (p) were given for panel regression models in the study. The coefficient of determination for all three models (), F-statistics, and significance values (p) of the model were given. Econometric analyses were performed with R-Project software (R Core Team, 2021). The plm package was used for the estimation of panel regression models (Croissant and Millo, 2018). The significance of the analysis results was evaluated according to $1 \%, 5 \%$ and $10 \%$ margin of error.

\subsection{Findings of the Research}

Durbin-watson test is a test used to determine the autocorrelation problem in the model. In our research article, the autocorrelation problem was tested with the Breusch-Godfrey / Wooldridge test developed specifically for panel data. Hausman test was applied in order to determine the effect type in model selection and the most suitable effect type was selected according to the test findings.

Table 2. Levin-Lin and Maddala-Wu Panel Stationaritv Test Results Applied For The Variables

\begin{tabular}{|c|c|c|c|c|c|c|c|c|}
\hline \multirow{3}{*}{ Variable } & \multicolumn{4}{|c|}{ Levin-Lin test } & \multicolumn{4}{|c|}{ Maddala-Wu test } \\
\hline & \multicolumn{2}{|c|}{ Constant } & \multicolumn{2}{|c|}{ Constant+Trend } & \multicolumn{2}{|c|}{ Constant } & \multicolumn{2}{|c|}{ Constant+Trend } \\
\hline & Statistic & $\mathrm{p}$ & Statistic & $\mathrm{p}$ & Statistic & $\mathrm{p}$ & Statistic & $\mathrm{p}$ \\
\hline PCE & -3.803 & 0.009 & -3.839 & 0.032 & 14.238 & 0.001 & 13.088 & 0.001 \\
\hline $\mathrm{HCE}$ & -4.662 & 0.001 & -4.910 & 0.003 & 24.476 & 0.000 & 20.907 & $<0.01$ \\
\hline SCE & -2.776 & 0.077 & -2.681 & 0.252 & 9.291 & 0.010 & 5.634 & $<0.01$ \\
\hline ROE & -2.775 & 0.077 & -3.089 & 0.131 & 4.976 & 0.083 & 7.886 & 0.019 \\
\hline PCR & -2.727 & 0.084 & -2.544 & 0.306 & 6.272 & 0.043 & 4.410 & 0.110 \\
\hline OPM & -5.158 & $<0.01$ & -5.429 & 0.001 & 30.693 & 0.000 & 27.847 & $<0.01$ \\
\hline SIZE & -2.401 & 0.152 & -2.306 & 0.415 & 5.537 & 0.063 & 3.214 & 0.200 \\
\hline FLR & -2.830 & 0.069 & -3.116 & 0.125 & 7.490 & 0.024 & 4.804 & 0.091 \\
\hline PCI & -2.378 & 0.158 & -2.353 & 0.392 & 4.294 & 0.117 & 2.217 & 0.330 \\
\hline
\end{tabular}


Table 2 shows the results of the Levin-Lin Maddala-Wu panel stationarity test applied under constant and constant + trend for all dependent and independent variables. According to the results of the stationarity test, PCE, HCE and OPM variables were found to be stationary at their levels within the scope of both constant and constant + trend. However, it was deter- mined that the variables SCE, ROE, PCR, SIZE, FLR and PCI were not stationary as a result of the constant and constant + trend stationarity tests. Accordingly, the first differences of SCE, ROE, PCR, SIZE, FLR and $\mathrm{PCI}$ variables were taken (D), and the data were made stationary and included in panel regression models.

Table 3. Panel Regression Equations Created for Dependent Variables

\begin{tabular}{lc}
\hline Model & Panel regression equations \\
\hline Model-1 & $\mathrm{D}(\mathrm{ROE})=\alpha_{i t}+\beta_{1} \mathrm{D}(\mathrm{SIZE})+\beta_{2} \mathrm{D}(\mathrm{FLR})+\beta_{3} \mathrm{D}(\mathrm{PCI})+\beta_{4} P C E+\beta_{5} H C E+\beta_{6} \mathrm{D}(\mathrm{SCE})+\varepsilon_{i t}$ \\
Model-2 & $\mathrm{D}(\mathrm{PCR})=\alpha_{i t}+\mathrm{D}\left(\beta_{1}\right.$ SIZE $)+\beta_{2} \mathrm{D}(\mathrm{FLR})+\beta_{3} \mathrm{D}(\mathrm{PCI})+\beta_{4} P C E+\beta_{5} H C E+\beta_{6} \mathrm{D}(\mathrm{SCE})+\varepsilon_{i t}$ \\
Model-3 & $\mathrm{OPM}=\alpha_{i t}+\mathrm{D}\left(\beta_{1} \mathrm{SIZE}\right)+\beta_{2} \mathrm{D}(\mathrm{FLR})+\beta_{3} \mathrm{D}(\mathrm{PCI})+\beta_{4} P C E+\beta_{5} H C E+\beta_{6} \mathrm{D}(\mathrm{SCE})+\varepsilon_{i t}$ \\
\hline
\end{tabular}

Table 3 shows the equations of the panel regression mo-

Table 4. Hausman Test Results

dels $(i=1,2,3,4,5,6 ; t=2016,2017,2018,2019,2020)$ created for the variables of ROE, PCR and OPM. Accordingly, panel regression models were estimated by taking ROE for Model-1, PCR for Model-2, and OPM for Model-3 as dependent variables.

In Table 4, the Hausman test results for Model-1, Model-2 and Model-3 are presented. According to the significance of the test statistics, it was concluded that it

\begin{tabular}{|c|c|c|c|}
\hline \multirow{2}{*}{$\begin{array}{l}\text { Hausman } \\
\text { Test }\end{array}$} & \multicolumn{3}{|c|}{ Model } \\
\hline & Model-1 & Model-2 & Model-3 \\
\hline Statistic & 3.110 & 3.357 & 3.932 \\
\hline $\mathrm{p}$ & 0.795 & 0.763 & 0.686 \\
\hline
\end{tabular}

was appropriate to choose the constant effect type for all three models.

Table 5. Auto-correlation and Heteroscedasticity Test Results

\begin{tabular}{lccc}
\hline \multirow{2}{*}{ Test } & \multicolumn{3}{c}{ Model } \\
\cline { 2 - 4 } & Model-1 & Model-2 & Model-3 \\
\hline Breusch-Godfrey / Wooldridge test & 12.312 & 12.462 & 14.559 \\
Statistic & $\mathbf{0 . 0 1 5}$ & $\mathbf{0 . 0 1 4}$ & $\mathbf{0 . 0 0 6}$ \\
$\mathrm{p}$ & & & \\
\hline Breusch-Pagan test & 4.983 & 3.285 & 2.152 \\
Statistic & 0.546 & 0.772 & 0.905 \\
$\mathrm{p}$ & & & \\
\hline
\end{tabular}

In Table 5, the results of Breusch-Godfrey / Wooldridge and Breusch-Pagan tests applied to check auto-correlation and heteroscedasticity assumptions in panel regression models are given. According to these results, it was determined that there was an auto-correlation problem for all three models, and that there was no heteroscedasticity problem.

Table 6. Coefficient and Model Statistics for Panel Regression Models

\begin{tabular}{|c|c|c|c|c|c|c|}
\hline \multirow{2}{*}{ Coefficient } & \multicolumn{2}{|c|}{ Model-1 } & \multicolumn{2}{|c|}{ Model-2 } & \multicolumn{2}{|c|}{ Model-3 } \\
\hline & Beta & $\mathrm{p}$ & Beta & $\mathrm{p}$ & Beta & $\mathrm{p}$ \\
\hline $\mathrm{D}$ (SIZE) & 0.00209 & 0.021 & 0.02386 & 0.066 & -0.01220 & 0.655 \\
\hline D (FLR) & 0.02672 & 0.068 & 1.10076 & $<0.01$ & 0.26668 & 0.041 \\
\hline $\mathrm{D}(\mathrm{PCI})$ & 0.40722 & 0.325 & 5.30681 & 0.383 & 8.09009 & 0.319 \\
\hline PCE & -0.00005 & 0.561 & 0.00082 & 0.586 & 0.01074 & 0.004 \\
\hline $\mathrm{HCE}$ & -0.00013 & $<0.01$ & -0.00145 & $<0.01$ & 0.02781 & $<0.01$ \\
\hline $\mathrm{D}(\mathrm{SCE})$ & 0.02038 & $<0.01$ & 0.22207 & $<0.01$ & 0.02410 & 0.730 \\
\hline $\mathrm{R}^{2}$ & \multicolumn{2}{|c|}{0.569} & \multicolumn{2}{|c|}{0.806} & \multicolumn{2}{|c|}{0.990} \\
\hline F-statistic & \multicolumn{2}{|c|}{3.740} & \multicolumn{2}{|c|}{11.768} & \multicolumn{2}{|c|}{280.264} \\
\hline $\mathrm{p}$ & \multicolumn{2}{|c|}{0.015} & \multicolumn{2}{|c|}{$<0.01$} & \multicolumn{2}{|c|}{$<0.01$} \\
\hline
\end{tabular}


Table 6 shows the coefficient statistics of the panel regression models estimated for ROE, PCR and OPM and the performance measures of the model. According to these measurements, based on the values of the models, the independent variables explain the dependent variables at a sufficient level, and according to the F-statistics, all models are statistically significant.

\section{CONCLUSION}

Today, it is important for businesses to fully report their market values in financial statements in terms of providing transparent, accurate, reliable and complete information to financial statement users. Intellectual capital, which includes important values that will benefit businesses in the future, cannot be presented in financial statements prepared based on historical data. Reporting the intellectual capital in the financial statements is important in terms of producing truthful information. It can be said that businesses create more value with their intellectual capital compared to their physical and financial capital. It is important to make intellectual capital visible, measure it, and observe its effects on business performance.

According to the panel regression coefficients, it was seen that size, financial leverage ratio, human capital efficiency and structural capital efficiency had statistically significant effects on return on assets and return on equity. When the panel regression coefficients are analyzed, it was seen that size, financial leverage ratio and structural capital efficiency had a positive effect on return on assets and return on equity, while human capital efficiency had a negative effect. According to the results of the model estimated for operating profit margin, it was seen that financial leverage ratio, physical capital efficiency and human capital efficiency had a statistically significant effect on operating profit margin. When the panel regression coefficients were examined, it was seen that financial leverage ratio, physical capital efficiency and human capital efficiency had a positive effect on operating profit margin. According to the results obtained from the research findings, it was determined that the intellectual capital efficiency of participation banks had a positive effect on financial performance. The research findings support previous studies conducted in different sectors and carried out with different methods.

\section{REFERENCES}

AL-MUSALI, M. A. K. \& ISMAIL KU, I. N. K. (2014). Intellectual Capital and Its Effect on Financial Performance of Banks: Evidence from Saudi Arabia. Procedia-Social and Behavioral Sciences, 164: 201-207.

APPUHAMI, B. A. R. (2007). The Impact of Intellectual Capital on Investor's Capital Gains on Shares: An Empirical Investigation of Thai Banking. Finance and Insurance Sector. International Management Review, 3(2): 14- 25.

BONTIS, N., KEOW, W.C. \& RICHARDSON, S. (2000). Intellectual Capital and Business Performance in Malaysian Industries. Journal of Intellectual Capital, 1(1): 85-100.

CROISSANT, Y. \& MILLO, G. (2018). Panel Data Econometrics with $R$ : the plm package. Wiley.

ÇALIŞKAN, T. (2015). Bilgi Ekonomisinde Entelektüel Sermaye: Borsa İstanbul'da Bankacılık Sektörü Uygulaması. Yönetim ve Ekonomi Araştırmaları Dergisi, 13(3): 121-137.

ÇIKRIKÇI, M. \& DAŞTAN, A. (2002). Entelektüel Sermayenin Temel Finansal Tablolar Aracılığıyla Sunulmas1. Bankacilar Dergisi, 43: 18-32.

DEMIRKOL, İ. (2006). Entelektüel Sermayenin Firma Değerine Etkisi ve İMKB'de Sektörel Uygulamalar. (Doktora Tezi). Gazi Üniversitesi Sosyal Bilimler Enstitüsü.

DRISCOLL, J. C. \& KRAAY, A. C. (1998). Consistent Covariance Matrix Estimation with Spatially Dependent Panel Data. Review of Economics and Statistics, 80(4): 549-560.

EL-BANNANY, M. (2008). A Study of Determinants of Intellectual Capital Performancein Banks: The UK Case. Journal of Intellectual Capital, 9(3): 487-498.

EKIM, N., ACAR, M. \& UÇAN, O. (2019). Entelektüel Sermayenin Finans Sektöründe Değer Yaratmadaki Rolü: Türk Bankacılık Sektöründe Bir Araştırma. Verimlilik Dergisi, (4): 37-63.

ERCAN, M. K., ÖZTÜRK, M. B. \& DEMIRGÜNEŞ, K. (2003). Değere Dayal Yönetim ve Entelektüel Sermaye. Gazi Kitabevi: Ankara.

FAYEZ, A., HAMEED, A. \& RIDHA, A. (2011). The Intellectual Capital Performance Of Kuwaiti Banks: An Application of VAIC(TM) 1 Model, Business, 3: 88-96.

GIGANTE, G. (2013). Intellectual Capital and Bank Performance in Europe. Accounting and Finance Research, 2(4): 120-129.

GÖKER, İ. E. K. (2017). “Bilişim Sektöründe Entelek- 
tüel Sermaye ile Finansal Performans İlişkisinin. Belirlenmesine Yönelik Bir Araştırma", 3(14): 78-86.

JOSHI, M., CAHILL, D., SIDHU, J. \& KANSAL, M. (2013). Intellectual Capital and Financial Performance: An Evaluation of the Australian Financial Sector. Journal of Intellectual Capital, 14(2): 264-285.

MAHERAN, N. M. \& KHAIRU, A. I., (2009). Intellectual Capital Efficiency and Firm's Performance: Study of Malaysian Financial Sectors. International Journal of Economics and Finance, 1(2): 206-212.

MONDAL, A. \& GHOSH, S. K. (2012). Intellectual Capital and Financial Performance of Indian Banks, Journal of Intellectual Capital, 13(4): 515-530.

ODABAŞOĞLU, Ş. (2019). Havayolu İşletmelerinde Entelektüel Sermayenin Piyasa Değeri-Defter Değeri Oranına Etkileri. Journal of Aviation Research, 1(1): 1-23.

OUSAMA, A. A. \& FATIMA, A. H. (2015), Intellectual Capital and Financial Performance of Islamic Banks. International Journal of Learning and Intellectual Capital, 12 (1): 1-15.

ÖNCE, S. (1999). Muhasebe Bakış Açısı ile Entelektüel Sermaye. Eskişehir: Eskişehir Anadolu Üniversitesi Yayınları.

ÖZDEMIR, S. \& KAYA, Y. (2019), Entelektüel Sermayenin Ölçülmesinde ve Raporlanmasında Kullanılan Yöntemler: Türkiye Banka Sektöründe Bir Uygulama, Pamukkale Üniversitesi Sosyal Bilimler Enstitüsü Dergisi, 35(269-284).

ÖZTOPANLAR, T. (2019). Entelektüel Sermaye ve Sürdürülebilirliğin Bankaların Finansal Performansı Üzerindeki Etkileri: Türk Bankacıllk Sektöründe Bir Araştırma. (Yayınlanmamış Yüksek Lisans Tezi). Necmettin Erbakan Üniversitesi, Sosyal Bilimler Enstitüsü İşletme Anabilim Dalı, Konya.

ÖZEVREN, M. \& YILDIZ, S. (2010). Entelektüel Sermayenin Ölçüm Yöntemleri ve Kriterlerinin Belirlenmesi Üzerine Bir Araştırma. Marmara Üniversitesi İ.I. B.F. Dergisi, XXIX(1): 275-289.

R Core Team (2021). R: A Language and Environment for Statistical Computing. R Foundation for Statistical Computing, Vienna, Austria.

SAENGCHAN, S. (2008). The Role of Intellectual Capital in Creating Value in the (Thai) Banking Industry, https://citeseerx.ist.psu.edu/viewdoc/download?do$\underline{\mathrm{i}=10.1 .1 .570 .8066 \& \mathrm{rep}=\mathrm{rep} 1 \& \text { type }=\mathrm{pdf}}$ (Erişim Tarihi: 01.02.2021).

STEWART, T. A. (1991). Brainpower, Fortune Dergisi, 123(11): 44-54.

STEWART, T. A. (1997). Entellektüel Sermaye Kuruluşla- rın Yeni Zenginliği, Çev. Nurettin Elhüseyni, İstanbul: MESS Yayınları.

SÜMERLI SARIGÜL, S. (2020). Entelektüel Sermayenin Ölçülmesi, Finansal Tablolara Yansıması ve Raporlanmasına Yönelik Bir Araştırma. Uluslararası Yönetim Akademisi Dergisi, 3(2): 427-443

ŞAMILOĞLU, F. (2006). Entelektüel Sermaye: İMKB'de Hisse Senetleri İşlem Gören Bankalar Üzerine Bir Uygulama, Muhasebe ve Finansman Dergisi, S.31, ss.78-89.

TÖRE, E. (2019). Entelektüel Sermayenin Yenilikçi İş Davranışına Etkisinde Bilgi Paylaşımının Aracı Rolü. Yönetim Bilimleri Dergisi, 17 (34): 275-299.

YALAMA, A. \& COŞKUN, M. (2007). Intellectual Capital Performance of Quoted Banks on The Istanbul Stock Exchange Market. Journal Of Intellectual Capital, 8(2): 256-271.

YALAMA, A. (2013). The Relationship Between Intellectual Capital and Banking Performance İn Turkey: Evidence from Panel Data. International Journal of Learning and Intellectual Capital, 10(1): 71-87. 